\title{
ERRATUM
}

\section{Bug juice: harvesting electricity with microorganisms}

Derek R. Lovley

Nature Reviews Microbiology 4, 497-508 (2006), doi:10.1038/nrmicro1442

In the above article, reference 68 was absent from the reference list and reference 69 was repeated. The missing reference is listed below. We wish to apologize to the author and to readers for any confusion caused.

68. Finneran, K. T., Johnsen, C. V. \& Lovley, D. R. Rhodoferax ferrireducens gen. nov., sp. nov.; a psychrotolerant, facultatively anaerobic bacterium that oxidizes acetate with the reduction of Fe(III). Int. J. Syst. Evol. Microbiol. 53, 669-673 (2003).

(c) 2006 Nature Publishing Group 